\title{
Lead, Arsenic, and Cadmium Contamination and Its Impact on Children's Health in La Oroya, Peru
}

\author{
Matthew K. Reuer, ${ }^{1}$ Nathan W. Bower, ${ }^{1}$ Jed H. Koball, ${ }^{2}$ Esther Hinostroza, ${ }^{3}$ \\ María Erlinda De la Torre Marcas, ${ }^{3}$ Jaime Alberto Hurtado Surichaqui, ${ }^{3}$ \\ and Sherly Echevarria ${ }^{3}$ \\ ${ }^{1}$ Department of Chemistry and Biochemistry, Colorado College, 14 E. Cache La Poudre Street, Colorado Springs, \\ CO 80903, USA \\ ${ }^{2}$ Red Uniendo Manos Perú, Jr. Daniel Alcides Carrión 844 B, Magdalena del Mar, Lima, Peru \\ ${ }^{3}$ Filomena Tomaira Pacsi, Avenida Tupac Amaru 101, La Oroya, Junín, Peru
}

Correspondence should be addressed to Matthew K. Reuer, mreuer@coloradocollege.edu

Received 25 August 2011; Accepted 3 October 2011

Academic Editors: J. Kirigia, E. Lazcano-Ponce, and T. S. Nawrot

Copyright (C) 2012 Matthew K. Reuer et al. This is an open access article distributed under the Creative Commons Attribution License, which permits unrestricted use, distribution, and reproduction in any medium, provided the original work is properly cited.

The large scale of nonferrous metal smelting has created a chronic public health issue in La Oroya, Perú. In this reconnaissance study, the distributions of lead, arsenic, and cadmium in drinking water, indoor dust, and soil were measured at five sites to estimate their impact on children's health. As expected, median soil metal levels dropped exponentially with distance from the smelting complex (3,177 ppm Pb, 1,658 ppm As, and 127 ppm Cd at La Oroya Antigua). Indoor dust metal concentrations were also elevated at La Oroya Antigua (2,574 ppm Pb, 1,071 ppm As, 28 ppm Cd), and drinking water As values were elevated relative to $\mathrm{Pb}$ and $\mathrm{Cd}(8.5 \mathrm{ppb} \mathrm{As}, 0.28 \mathrm{ppb} \mathrm{Pb}$, and $0.05 \mathrm{ppb} \mathrm{Cd}$ ), suggesting selective loss of $\mathrm{Pb}$ and $\mathrm{Cd}$ relative to As. Exposure and doseresponse modeling (IEUBK) indicate soil $\mathrm{Pb}$ and $\mathrm{As}$ are serious health problems in need of remediation.

\section{Introduction}

Reduced anthropogenic emissions of lead $(\mathrm{Pb})$, arsenic (As), cadmium $(\mathrm{Cd})$, mercury $(\mathrm{Hg})$, and other heavy metals have been well documented in terrestrial ecosystems, atmospheric emissions, and marine ecosystems [1-4]. However, some of this environmental burden has been shifted to nations where equivalent regulations or enforcement are limited $[5,6]$. Deleterious environmental and public health issues are frequently associated with nonferrous metal smelting, including emissions in North America [7-9], China [10], Australia [11, 12], Latin America [13, 14], and Africa [15]. The city of La Oroya, Peru, has been similarly affected by heavy metal mining and smelting since 1922, although limited environmental observations have been made despite a clear public health concern [16]. This reconnaissance survey examines the lead, arsenic, and cadmium content of drinking water, indoor dust, and soil to quantify the environmental impact and associated health risk to the children of La Oroya.
Operation of a metallurgical complex less than a kilometer from La Oroya Antigua has created a human health issue for its 33,000 residents [17], notably children, due to the neurological and cognitive impairments associated with metal poisoning (e.g., $[18,19])$. In La Oroya Antigua, the pediatric blood $\mathrm{Pb}$ levels were approximately three times the accepted level of concern in $1999\left(34 \mu \mathrm{g} \mathrm{dL}^{-1}\right.$ compared to the $10 \mu \mathrm{g} \mathrm{dL}^{-1}$ World Health Organization critical level [16]). For excellent reviews of the La Oroya environmental, socioeconomic, and public health issue, see Fraser [20] and Cederstav and Barandiarán [16]. Despite continuous operation from 1922, the smelter complex ceased operation due to debt financing issues in 2009. Recent political discussions have focused on the soil remediation costs despite no available soil data in the public domain. This study examines how past and recent smelter emissions have impacted local soils, indoor dust, and drinking water in five locations near the metallurgical complex, focusing on three metals with known health risks $(\mathrm{Pb}, \mathrm{As}$, and $\mathrm{Cd})$ to 
determine the relative importance of these different vectors to children's health.

The environmental impacts of smelter emissions have been well established by observations in North America, emphasizing the importance of point source stack and fugitive emissions and their exponential reduction with distance (see Figure 1 of Roberts et al. [8]). Approximately half of the total aerosol $\mathrm{Pb}$ content is found in the submicron particulate fraction, suggesting it could be readily transported several kilometers from the point source [7]. The Landrigan et al. [7] study of the El Paso, Texas ASARCO smelter is particularly relevant given its limited emission control technology and close proximity to a population center. The measured airborne $\mathrm{Pb}$ emission was from 8 to $10 \mu \mathrm{g} \mathrm{m}^{-3}$, although the annual mean $\mathrm{Pb}$ aerosol concentration immediately downwind of the smelter was $92 \mu \mathrm{g} \mathrm{m}^{-3}$. For comparison, the World Health Organization (WHO) air quality guideline for aerosol $\mathrm{Pb}$ is $0.5 \mu \mathrm{g} \mathrm{m}^{-3}$ [21]. Within 200 meters of the smelter, El Paso geometric mean soil $\mathrm{Pb}$ was $3,457 \mathrm{ppm}$ (ranging from 560 to $11,450 \mathrm{ppm}, n=54$ ), significantly above the USEPA hazard standard of 1,200 ppm for bare soil (Toxic Substances Control Act, Section 403, USEPA, 2001 [22]). Household dust samples were similarly elevated adjacent to the smelter (the Smeltertown geometric mean $\mathrm{Pb}$ content was 22,191 ppm, $n=51$ ).

The potential environmental impacts of the La Oroya metallurgical complex are clear. First, the smelter facility was in continuous operation from 1922 to 2009, suggesting the accumulation of heavy metals in regional soils, biota, and other environmental media. Second, the nearest permanent residence of La Oroya Antigua is located approximately 320 meters from the stack point source (compared to the town center at approximately 700 meters and the most distant residence at $1.4 \mathrm{~km}$; distances are straight line to the point source). However, nonpoint source, fugitive emissions must also be considered, including a $\mathrm{Pb}$ concentrator in Nueva La Oroya. Third, atmospheric temperature inversions during the winter months can trap emissions close to the town center, concentrating atmospheric $\mathrm{Pb}$ aerosols along the Rio Mantaro Valley. Finally, nearby carbonaceous slag piles located 1.3 to $2.1 \mathrm{~km}$ southeast of the complex also contain elevated concentrations of these same metals. (Preliminary data from March 2010 showed percent level Pb, As, and Cd in two slag samples, unpublished observation.)

Two mitigating factors are advective transport of aerosols away from La Oroya Antigua and increased use of emission control technologies by the facility operator since 1997 [23]. Although no meteorological data are publically available for La Oroya Antigua, a nearby station in Santa Rosa de Sacco provides daily wind speed and direction data from 2006 to 2011 (available from SEMNAHI, Servicio Nacional de Meteorologia e Hidrologia del Peru, http://www.senamhi.gob.pe/, accessed June 2011). Wind rose analysis of these data indicates a dominant northeasterly wind direction. (The resultant flow vector was 218 degrees at $82 \%$ probability, not shown.) In the absence of topographic steering, this would transport smelter emissions away from La Oroya Antigua and towards Santa Rosa de Sacco and Yauli (Figure 1). Second, addition of emission control technology would improve environmental quality. According to the current facility operator (Doe Run Peru), aerosol Pb, As, and Cd concentrations in La Oroya Antigua dropped 62\%, 85\%, and 67\%, respectively, between 1995 and 2000.

The best available environmental data from the La Oroya district comes from quarterly air quality reports from the facility operator (Doe Run Peru) to the Ministry of Energy and Mines (MEM), as summarized by Cederstav and Barandiarán [16]. The quality control procedures for these results are unknown. However, these direct observations from 1995 to 2000 demonstrate that significant metal aerosol deposition has occurred in the past. Five air quality monitoring stations were reported, ranging from 0.8 to $3.0 \mathrm{~km}$ from the point source (see Figure 1 for their locations). For the heavy metals, aerosol $\mathrm{Pb}, \mathrm{As}$, and $\mathrm{Cd}$ values were consistently elevated at the Huanchán monitoring station, located $2 \mathrm{~km}$ downwind of the facility in the Rio Mantaro Valley. Mean annual atmospheric $\mathrm{Cd}$ concentrations ranged from 0.2 to $1.0 \mu \mathrm{g} \mathrm{m}^{-3}$ at Huanchán, whereas the upwind stations such as Casaracra reported concentrations less than $0.1 \mu \mathrm{g} \mathrm{m}^{-3}$ [16]. Arsenic and lead concentrations were similarly elevated and variable at Huanchán, ranging from 2 to $8 \mu \mathrm{g} \mathrm{m}^{-3}$ (As) and from 3 to $21 \mu \mathrm{g} \mathrm{m}^{-3}(\mathrm{~Pb})$. As the atmospheric values are significantly above $\mathrm{WHO}$ air quality guidelines for contaminated aerosols $\left(0.5 \mu \mathrm{g} \mathrm{m}^{-3} \mathrm{~Pb} ; 5 \mathrm{ng} \mathrm{m}^{-3} \mathrm{Cd}\right)$, contamination of regional soils, dust, and drinking water would be expected due to historical and recent operation of the metallurgical complex.

Elevated pediatric blood $\mathrm{Pb}$ levels and the associated neurological impairment can result from smelter emissions: Landrigan et al. [7] measured blood Pb levels $>40 \mu \mathrm{g} \mathrm{dL}^{-1}$ in 53 percent of children 1-9 years of age living within $1.6 \mathrm{~km}$ of the El Paso, Texas ASARCO smelter, whereas 18 percent of children had comparable blood $\mathrm{Pb}$ levels within 1.6 to $6.6 \mathrm{~km}$. As La Oroya Antigua is located a comparable distance to the smelter facility, one might expect similar elevated blood Pb levels: Ramírez et al. [17] measured mean blood $\mathrm{Pb}$ concentrations of $34.8 \pm 4.0 \mu \mathrm{g} \mathrm{dL}^{-1}$ between 1994-1995 in $80 \mathrm{La}$ Oroya residents, compared to $14.0 \pm 2.7 \mu \mathrm{g} \mathrm{dL}^{-1}$ in a control group from Yaupi and $22.4 \pm 4.7 \mu \mathrm{g} \mathrm{dL}^{-1}$ from an additional Huancayo control group. Subsequent studies have confirmed elevated blood $\mathrm{Pb}$ concentrations in La Oroya residents, notably measurements by the environmental health ministry (Dirección General de Salud Ambiental, DIGESA) and the facility operator Doe Run Peru. As summarized by Cederstav and Barandiarán [16], the DIGESA results from 1999 indicated blood $\mathrm{Pb}$ levels from 6.9 to $79.9 \mu \mathrm{g} \mathrm{dL}^{-1}$ with a mean of $33.6 \mu \mathrm{g} \mathrm{dL}^{-1}$ ( $n=346,2$ - to 10-year-old children). Recent measurements have shown a decline to $23.4 \mu \mathrm{g} \mathrm{dL}-1$ in November 2007, but still approximately twice the $10 \mu \mathrm{g} \mathrm{dL}^{-1}$ level of concern [21]. Significant cognitive impairments have also been reported for pediatric blood $\mathrm{Pb}$ levels below $10 \mu \mathrm{g} \mathrm{dL}^{-1}$, suggesting that any pediatric exposure to environmental $\mathrm{Pb}$ poses some health risks $[24,25]$. In this study, we adopt the $10 \mu \mathrm{g} \mathrm{dL} L^{-1}$ threshold as a comparative value while acknowledging the risk below this concentration.

Despite the public health risks to the La Oroya region, we know of no published studies that have measured metal concentrations in local soils, dust, drinking water, or other 


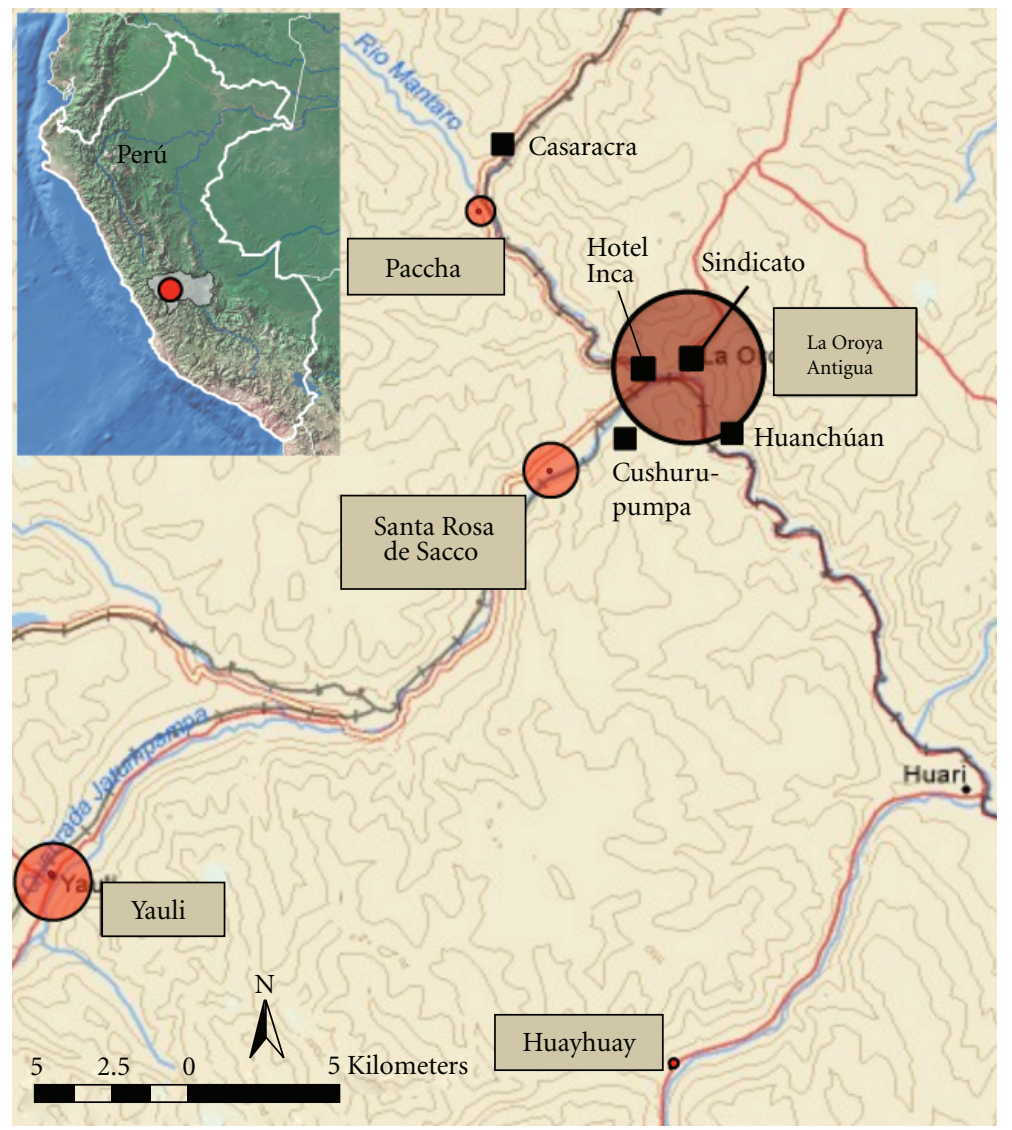

FIgURE 1: Site location map for the La Oroya study area. The five study locations are shown as red circles, scaling the diameter to the median soil $\mathrm{Pb}$ concentration (186 ppm for Huayhuay to 3,177 ppm for La Oroya Antigua). Note the site distribution and the difference in soil $\mathrm{Pb}$ between the two distant sites Yauli and Huayhuay. The five Doe Run Peru air monitoring stations are shown as black squares, and the monitoring locations are adopted from Cederstav and Barandiarán [16].

environmental media. Thus the current relationship between the environmental contamination and human health is unclear. We did not measure dietary levels. (This remaining vector could also be significant if food is grown locally on soils with comparable levels to those measured here.) Although a variety of exposure pathways have been discussed for the La Oroya population, establishing the principal vectors is critical given the severity of the problem and limited resources to address the issue.

\section{Methods}

This study examines five sites located 1 to $26 \mathrm{~km}$ from the smelting complex, including one site (Yauli) with a secondary source of heavy metals. Our observations include three key environmental media: surface soil, drinking water, and indoor dust concentrations. In this study, we also adopt simple exposure calculations and the Integrated Exposure Uptake Biokinetic (IEUBK) Model for Lead in Children [26]. This comparison will better optimize the scale and nature of remediation efforts in this region.

2.1. Site Description. As shown in Figure 1, the city of La Oroya Antigua is located in the central Peruvian Altiplano at 3,745 meters elevation, approximately $180 \mathrm{~km}$ east of the capital Lima (Junín region, Yauli province, La Oroya district). The regional physiography is dominated by steep valleys of the Rio Mantaro and Rio Yauli, located within the central Andean puna and tundra ecoregions (see Figure 2 of [27]). The predominant vegetation is native bunch grasses (genera Festuca, Calamagrostis, and Agrostis, [28]), although in many contaminated areas surrounding La Oroya Antigua sparse above-ground biomass exists.

The Yauli-La Oroya Province has a population of 67,724 residents, with approximately 33,000 residents in the $\mathrm{La}$ Oroya district [29]. Depopulation of workers has occurred following the closure of the metallurgical complex. The majority of residents in the province (92\%) reside in urban areas, and most households (62\%) cannot meet basic needs (ibid.). Mining and metallurgy represents the largest provincial industry, employing 6,239 full-time and 3,277 part-time workers in 1993 (ibid.). In 2005, Doe Run Peru employed 2,898 full-time employees and 1,185 contractors, both in the La Oroya district and the Cobriza Mine, representing the largest employer in La Oroya [23].

Small-scale mining of precious metals first started in 1533 during the Spanish colonial period, but railroad development in 1893 catalyzed greater regional mining 
activity (e.g., the Cerro de Pasco and Morococha districts), transporting mining products from La Oroya to the Port of Callao [30]. Copper smelting began in 1922 with the Cerro de Pasco Copper Corporation, followed by lead (1928) and zinc (1952) smelting [23]. Because of the mixed composition of regional ores, the facility recovers a wide variety of metal byproducts, including gold, silver, arsenic, antimony, cadmium, and bismuth. Only five other smelting facilities in the western hemisphere can process lead and copper concentrates with these complex mixtures. The La Oroya facility competes with several Chinese facilities for these mixed raw materials from South American mining districts [23].

In 1974 the metallurgical complex was nationalized by the state-owned Empresa Minera del Centro del Peru S. A. (CENTROMIN) and its subsidiary, Metaloroya S. A. In 1997 the facility was privatized and purchased by Doe Run Peru. Upon privatization, Doe Run Peru was required to follow a series of environmental remediation steps known as PAMA (Programa de Adecuación y Manejo Ambiental), an environmental contract requiring nine specific remediation measures. Doe Run Peru did not meet the PAMA agreement by the initial deadline, resulting in an extension allowed by the Peruvian government until 2009 (Supreme Decree no. 046-2004-EM, [23]). Although significant improvements were made to the facility under the PAMA agreement, several modifications were not completed, notably the completion of the sulfuric acid processing plant. However, the metallurgical complex was shut down in 2009 due to inadequate debt financing and operational costs. Because Doe Run Peru was indemnified against any environmental liability in the 1997 PAMA agreement, remediation of the regional environment is currently debated both in Peru and the United States (Renco Group, the holding company for Doe Run Peru, is based in the USA). Doe Run Peru states facility investments of $\$ 315$ million were completed, with no comparable environmental remediation investments by the Peruvian government [31].

2.2. Site Selection. Surface soil, drinking water, and indoor dust samples were collected in August 2010 to test for $\mathrm{Pb}$, As, and Cd concentrations. Five population centers, shown in Figure 1, were chosen to evaluate how environmental media could affect a specific population, rather than using dispersed regional sampling. The five sites were chosen based on the following criteria: (1) variable distance and direction from the metallurgical complex; (2) available participants in the study; and (3) suspected contamination based on available health histories. Note that selecting a "control" site devoid of contamination is difficult as nonferrous metal aerosols travel global distances from their source as high temperature condensates and vapors (e.g., [32]). Other anthropogenic contributions from mining activities (ore concentration and transport), lead solder, tailings-derived aerosols, leaded gasoline, and leaded paints could also be significant factors at these sites and should not be discounted.

\subsection{Sample Analysis}

2.3.1. Soil Collection and Analysis. At each site, seven to thirteen outdoor soil samples were randomly selected based on the following criteria: (1) representative of the site (not imported soil), (2) common play areas for children (soccer fields, playgrounds, school yards, and open areas), and (3) adequate sample distribution. Any above-ground biomass was removed prior to soil sampling, and the top $1 \mathrm{~cm}$ of soil was removed with a clean plastic scraper over $100 \mathrm{~cm}^{2}$. Soil samples were placed into plastic bags, dried at room temperature, sieved with a $0.1 \mathrm{~mm}$ nylon/PVC sieve, and placed into $20 \mathrm{~mL}$ acid-leached HDPE sample vials. All plasticware used in this study was leached with reagent grade $1 \mathrm{~N} \mathrm{HCl}$ (Fisher Scientific, Pittsburgh, PA) for 48 hours at $55^{\circ} \mathrm{C}$ then triple-rinsed in $18 \mathrm{M} \Omega$ Milli-Q water (Milli-Q Gradient system, Billerica, MA). The smaller size fraction was the focus of this study as it poses a greater ingestion and inhalation health risk to children relative to the larger mineral grains. The sieved soil was dried at $70^{\circ} \mathrm{C}$ for 24 hours to remove all soil moisture then stored in a desiccator containing fresh Drierite (W. A. Hammond, Xenia, $\mathrm{OH}$ ) at room temperature. Prior to analysis, samples were homogenized in a Spex 8000 mixer (Metuchen, NJ) for two minutes. Samples were analyzed in sample cups through a $5 \mu \mathrm{m}$ thick, $36 \mathrm{~mm}$ diameter polypropylene window, (Spex, Metuchen, NJ) using energy dispersive Xray fluorescence (ED-XRF) with polarizing optics (Epsilon 5, PANalytical, Westborough, MA). Source scatter from yttrium and tungsten were removed prior to normalization. External calibration verification with matrix-matched National Institute of Science and Technology standard reference materials (metal contaminated soil 2710, 2710a, and 2711, Gaithersburg, Maryland) was performed daily. Limits of detection ( $\mathrm{LOD}=3$ sigma) were calculated from the daily SRM and blank measurements. The LODs were $340 \mathrm{ppm}$ for $\mathrm{Pb}, 66 \mathrm{ppm}$ for As, and $5 \mathrm{ppm}$ for $\mathrm{Cd}$. The ED-XRF detection limits and the calibration curves' coefficients of variation $(<10 \%)$ were not a significant source of uncertainty relative to intersample variability for $\mathrm{Pb}$ and As, though a few individual $\mathrm{Cd}$ samples were at the detection limit for this method.

2.3.2. Indoor Dust Collection and Analysis. Indoor dust samples were collected at the same five sites as the outdoor soil samples, including residential areas, schools, hospitals, churches, and municipal offices. Prior to visiting the site, occupants were contacted by a local NGO affiliate to gain consent, and a second confirmation was made while on site (rejections were common at the La Oroya Antigua site given the sensitivity of environmental sampling). Residents were asked not to clean any flooring surfaces prior to the sampling visit. Samples were collected with a clean nylon brush over a $1 \mathrm{~m}^{2}$ area; dust loading estimates were impossible given the prevalence of compacted clay floors or wooden slats above a clay foundation (indoor dust was continuously generated with sweeping). Inclusion of paint chips, food particles, and other dust materials was allowed in the bulk sample given the exposure of young children to these same particles. Leaded paint particles may have contributed to dust chemistry given its continued use in South America (see discussion below). Following collection of indoor dust, samples were treated identically to the soil samples as noted above. 
2.3.3. Drinking Water Sample Collection and Analysis. Drinking water samples were collected at each indoor dust sample location with permission. Occupants were asked to collect the sample identical to how they obtain their drinking water to mimic the appropriate flush conditions (as influenced by lead-containing solder or other contaminants). Samples were placed into acid-cleaned, $60 \mathrm{~mL}$ high density polyethylene bottles (VWR, Radnor, PA) and filtered through $0.45 \mu \mathrm{m}$ PTFE syringe filters (22 $\mathrm{mm}$ diameter, Pall, Port Washington, NY) to remove particulates. An acrylic syringe vise was utilized to push the sample through the hydrophobic membrane. Filtered samples were acidified to $\mathrm{pH} 2$ (verified with colorpHast $\mathrm{pH}$ strips, EM-Reagents, Darmstadt, Germany) using $150 \mu \mathrm{L}$ of trace metal grade $6 \mathrm{~N} \mathrm{HCl}$ within 12 hours of sample collection (Aristar Plus, BDH Chemicals, Radnor, $\mathrm{PA})$.

Elemental concentrations were determined by ICPMS (Agilent 7500ce) with gravimetrically prepared Spex Certiprep ICP standards (1000 $\mathrm{mg} \mathrm{L}^{-1}$ stock standards). NIST SRMs 1573 and 1575 were utilized to verify calibrations. Measurements were conducted at the Colorado State University-Pueblo EPA certified ICP-MS facility, using Method 6020. The ICP-MS utilizes an Octopole Reaction System (ORS) and an Integrated Sample Introduction System (ISIS). These remove potential interferences (e.g., $\mathrm{ArCl}$ on As) and lower the detection limits. Helium was used in the ORS for As, while $\mathrm{Cd}$ and $\mathrm{Pb}$ were conducted without the ORS. Nine different element/isotopes were used for internal standard corrections. Isotopes ${ }^{75} \mathrm{As},{ }^{111} \mathrm{Cd}$, and ${ }^{206} \mathrm{~Pb},{ }^{207} \mathrm{~Pb}$, and ${ }^{208} \mathrm{~Pb}$ were measured in the water samples using a torch depth of $8.0 \mathrm{~mm}, 1500 \mathrm{~W}$ RF Power, $0.80 \mathrm{~L} / \mathrm{min}$ carrier gas, and $0.20 \mathrm{~L} / \mathrm{min}$ makeup gas with a glass concentric nebulizer (MicroMist) and a Pt cone. Based on replicate SRM measurements, the 3 sigma limits of detection for $\mathrm{Pb}, \mathrm{As}$, and Cd were $0.05 \mathrm{ppb}$.

\section{Results and Discussion}

Summary statistics for $\mathrm{Pb}$, As, and $\mathrm{Cd}$ are shown in Table 1, including the soil, indoor dust, and drinking water observations by site (each site includes the arithmetic mean, geometric mean, median, range, and $95 \%$ confidence interval). Because the impact of outliers on small data sets is minimized, we used the median values for exposure modeling and the discussion here rather than the higher arithmetic mean. Changes to the median values could result from dry versus wet season sampling; the dry season values are reported in this study. Here the discussion focuses on the metal concentrations for each sample type, followed by the potential health impact.

3.1. Soil Concentrations. Box plots with medians and inner quartile ranges for $\mathrm{Pb}, \mathrm{As}$, and $\mathrm{Cd}$ soil concentrations are shown in Figure 2. Elevated metal concentrations are consistently observed in La Oroya Antigua $(3,177,127$, and $4,820 \mathrm{ppm}$ for the $\mathrm{Pb}, \mathrm{As}$, and $\mathrm{Cd}$ median values, resp.). These results demonstrate elevated metal concentrations and the highest variance close to the La Oroya metallurgical complex, with soil $\mathrm{Pb}$ concentrations ranging from 297 to
$11,451 \mathrm{ppm}$ in La Oroya Antigua. Variable metal concentrations near the point source would be expected based on the soil profile's erosional history (a stable surface versus a soil profile freshly eroded to depth), the cation exchange capacity of the soil (clay and organic matter content), mineralogy, and other factors. The depositional history of metal aerosols will also vary, depending on the prevailing wind direction and the aerosol size distribution.

For two of the five sites (La Oroya Antigua and Yauli), median soil $\mathrm{Pb}$ was greater than or equal to the $1,200 \mathrm{ppm}$ USEPA regulatory limit for bare soil [22]. At Santa Rosa de Sacco, the median soil $\mathrm{Pb}$ value $(1,152 \mathrm{ppm})$ is within error of the 1,200 ppm regulatory limit. Two sites, Paccha and Huayhuay had concentrations below 1,200 ppm, as expected for locations well upwind (Paccha) or a significant distance (Huayhuay, $22 \mathrm{~km}$ ) from the La Oroya smelter facility. Elevated $\mathrm{Pb}$ concentrations at Yauli (median soil $\mathrm{Pb}$ of $1,623 \mathrm{ppm}$ ), the most distant site from the metallurgical complex $(26 \mathrm{~km})$, suggest that another metal source must be considered. This is explained by (1) an active $\mathrm{Pb}$ concentrator facility at the southern edge of the community, where lump ore is processed into higher grade concentrates; (2) advection of tailing particulates stored close to the community in open piles; (3) dust from transport of ore in trucks and railroad cars that pass through the community; and/or (4) another unknown $\mathrm{Pb}$ source. Thus advection of contaminated aerosols from the La Oroya point source cannot explain all of the regional soil $\mathrm{Pb}$ observations.

To evaluate the point source impact on regional soil concentrations, the natural logarithms of the soil metal levels were calculated and then regressed versus distance from the smelter facility, using individual samples from four sites. The Yauli site was not included in the linear regression model due to the additional expected anthropogenic sources previously discussed. The linear regression fits are significant at the $99+\%$ confidence interval for all three metals (Pearson regression, $r=0.653, P<0.001$ for $\mathrm{Pb} ; r=0.792, P<0.001$ for Cd; $r=0.546, P=0.001$ for As, $\mathrm{df}=31$ ). There was no significant inhomogeneity of variance across the sites (Levene's test: $P=0.255$ for $\mathrm{Pb}, P=0.089$ for Cd, $P=0.095$ for As).

The mean atmospheric residence times for $\mathrm{Pb}, \mathrm{As}$, and $\mathrm{Cd}$ are comparable (8 to 12 days), so the differences among the three elements' levels observed across the four sites might reflect different chemistries in smelter stack emissions, or they may result from differences in ore processing. The oxides $\left(\mathrm{As}_{2} \mathrm{O}_{3}, \mathrm{CdO}\right.$, and $\left.\mathrm{PbO}\right)$ are the predominant species emitted in nonferrous smelter emissions [33], but As (V) is usually the predominant species found downwind [34], in keeping with predictions from redox potentials. These results suggest that atmospheric emissions from the metallurgical complex account for most of the regional variability in soil metal concentrations.

One soil outlier from La Oroya Antigua warrants consideration, as it greatly exceeded the $95 \%$ confidence interval of the sample population. This sample was collected immediately downwind of the smelter complex and southeast of the residential area. Highly elevated $\mathrm{Pb}(6.1 \%)$, As (2.4\%), and $\mathrm{Cd}(2,600 \mathrm{ppm})$ concentrations indicate this area has been 
TABle 1: Summary statistics for Pb, As, and Cd by site. The La Oroya Antigua results exclude one soil outlier measured immediately downwind from the metallurgical complex (see text for discussion). Confidence intervals are shown at the 95\% level (95\% C. I.).

\begin{tabular}{|c|c|c|c|c|c|c|c|c|c|c|}
\hline \multirow{2}{*}{ Site } & \multirow{2}{*}{ Statistic } & \multicolumn{3}{|c|}{ Soil } & \multicolumn{3}{|c|}{ Indoor dust } & \multicolumn{3}{|c|}{ Drinking water } \\
\hline & & $\mathrm{Pb}(\mathrm{ppm})$ & $\mathrm{Cd}(\mathrm{ppm})$ & As (ppm) & $\mathrm{Pb}(\mathrm{ppm})$ & $\mathrm{Cd}(\mathrm{ppm})$ & As (ppm) & $\mathrm{Pb}(\mathrm{ppb})$ & $\mathrm{Cd}(\mathrm{ppb})$ & As (ppb) \\
\hline \multirow{5}{*}{$\begin{array}{l}\text { La Oroya } \\
\text { Antigua } \\
n=7, \text { soil } \\
n=6, \text { dust } \\
n=5, \text { water }\end{array}$} & $\begin{array}{l}\text { Arithmetic } \\
\text { Mean }\end{array}$ & 5,070 & 257 & 2,600 & 4,621 & 94 & 1,405 & 0.42 & 0.06 & 8.98 \\
\hline & $\begin{array}{c}\text { Geometric } \\
\text { Mean }\end{array}$ & 3,138 & 137 & 1,844 & 3,413 & 45 & 1,109 & 0.28 & 0.05 & 8.90 \\
\hline & Median & 3,177 & 127 & 1,658 & 2,574 & 28 & 1,071 & 0.31 & 0.06 & 8.49 \\
\hline & Range & 11,154 & 583 & 4,820 & 12,484 & 335 & 3,313 & 0.90 & 0.07 & 3.61 \\
\hline & 95\% C. I. & 8,518 & 466 & 3,906 & 9,771 & 262 & 2,330 & 0.76 & 0.05 & 2.83 \\
\hline \multirow{5}{*}{$\begin{array}{l}\text { Santa Rosa de } \\
\text { Sacco } \\
n=10 \text {, soil } \\
n=6 \text {, dust } \\
n=5 \text {, water }\end{array}$} & $\begin{array}{l}\text { Arithmetic } \\
\text { Mean }\end{array}$ & 1,432 & 29 & 534 & 985 & 20 & 402 & 0.40 & 0.04 & 1.26 \\
\hline & $\begin{array}{c}\text { Geometric } \\
\text { Mean }\end{array}$ & 1,211 & 0 & 458 & 883 & 17 & 348 & 0.11 & 0.00 & 1.15 \\
\hline & Median & 1,152 & 23 & 442 & 813 & 18 & 317 & 0.09 & 0.00 & 1.16 \\
\hline & Range & 3,446 & 92 & 1,021 & 1,280 & 33 & 696 & 1.54 & 0.22 & 1.66 \\
\hline & 95\% C. I. & 1,998 & 54 & 640 & 1,010 & 24 & 514 & 1.31 & 0.20 & 1.21 \\
\hline \multirow{5}{*}{$\begin{array}{l}\text { Paccha } \\
n=7, \text { soil } \\
n=6, \text { dust } \\
n=5 \text {, water }\end{array}$} & $\begin{array}{c}\text { Arithmetic } \\
\text { Mean }\end{array}$ & 596 & 11 & 335 & 575 & 7 & 223 & 0.29 & 0.03 & 1.54 \\
\hline & $\begin{array}{c}\text { Geometric } \\
\text { Mean }\end{array}$ & 356 & 0 & 269 & 512 & 0 & 219 & 0.00 & 0.00 & 1.51 \\
\hline & Median & 613 & 18 & 275 & 457 & 4 & 231 & 0.06 & 0.00 & 1.63 \\
\hline & Range & 1,538 & 21 & 564 & 975 & 24 & 109 & 1.22 & 0.13 & 0.76 \\
\hline & 95\% C. I. & 1,116 & 20 & 484 & 730 & 18 & 84 & 1.05 & 0.11 & 0.60 \\
\hline \multirow{5}{*}{$\begin{array}{l}\text { Huayhuay } \\
n=8, \text { soil } \\
n=7, \text { dust } \\
n=5 \text {, water }\end{array}$} & $\begin{array}{c}\text { Arithmetic } \\
\text { Mean }\end{array}$ & 452 & 4 & 287 & 1,026 & 14 & 371 & 0.41 & 0.01 & 0.73 \\
\hline & $\begin{array}{c}\text { Geometric } \\
\text { Mean }\end{array}$ & 199 & 0 & 271 & 782 & 13 & 340 & 0.23 & 0.00 & 0.73 \\
\hline & Median & 186 & 4 & 269 & 587 & 15 & 324 & 0.20 & 0.00 & 0.72 \\
\hline & Range & 2,272 & 9 & 324 & 2,013 & 13 & 425 & 1.28 & 0.04 & 0.16 \\
\hline & 95\% C. I. & 1,524 & 6 & 220 & 1,534 & 10 & 314 & 1.07 & 0.03 & 0.12 \\
\hline \multirow{5}{*}{$\begin{array}{l}\text { Yauli } \\
n=13, \text { soil } \\
n=7, \text { dust } \\
n=5 \text {, water }\end{array}$} & $\begin{array}{c}\text { Arithmetic } \\
\text { Mean }\end{array}$ & 1,900 & 23 & 474 & 2,163 & 16 & 343 & 0.38 & 0.00 & 11.43 \\
\hline & $\begin{array}{c}\text { Geometric } \\
\text { Mean }\end{array}$ & 1,111 & 13 & 352 & 1,811 & 14 & 334 & 0.34 & 0.00 & 11.43 \\
\hline & Median & 1,623 & 18 & 298 & 2,228 & 15 & 303 & 0.34 & 0.00 & 11.38 \\
\hline & Range & 7,980 & 98 & 1,799 & 3,635 & 28 & 239 & 0.57 & 0.00 & 0.46 \\
\hline & 95\% C. I. & 4,092 & 54 & 1,004 & 2,698 & 18 & 174 & 0.44 & 0.00 & 0.18 \\
\hline
\end{tabular}

severely impacted by the smelter emissions. This sample was excluded from the analysis as it does not directly impact the community, but advection of mineral fines from this area and the nearby slag heaps might contribute to heavy metal contamination in La Oroya Antigua. Percent level metal concentrations indicate a possible economic incentive for soil remediation in the La Oroya district.

3.2. Indoor Dust Concentrations. As shown in Figure 3, $\mathrm{Cd}$ and As concentrations follow the expected regional trends, with elevated concentrations in La Oroya Antigua (28 ppm for Cd, 1071 ppm for As) relative to the other sites. Concentration variability is also greatest close to the point source. Elevated and variable metal concentrations follow the soil pattern, as most indoor mineral dust would be derived from local soils. In many cases, this relationship would be highly localized and not representative of the wider community, as dust from fenced outdoor work areas or courtyards would be transported through open doorways. Indoor dust might also be generated from localized areas in a community, such as a bare soccer field surrounded by residences in the case of Paccha. Overall, indoor dust Cd and As concentrations are elevated in La Oroya Antigua and diminish with distance from the point source.

The pattern for indoor dust $\mathrm{Pb}$ shows greater variability, as four of the five sites (La Oroya Antigua, Santa Rosa de Sacco, Huayhuay, and Yauli) exhibit indoor dust concentrations equal to or greater than the USEPA 1,200 ppm soil limit at the 95\% confidence interval. For the "control" site of Huayhuay, the indoor dust value $(587 \mathrm{ppm})$ is greater 


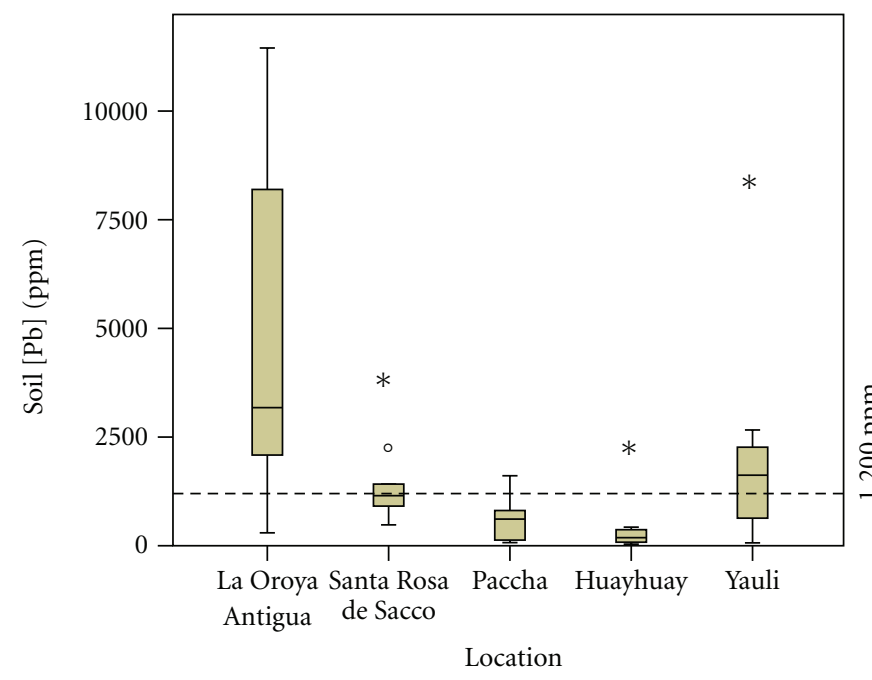

(a)

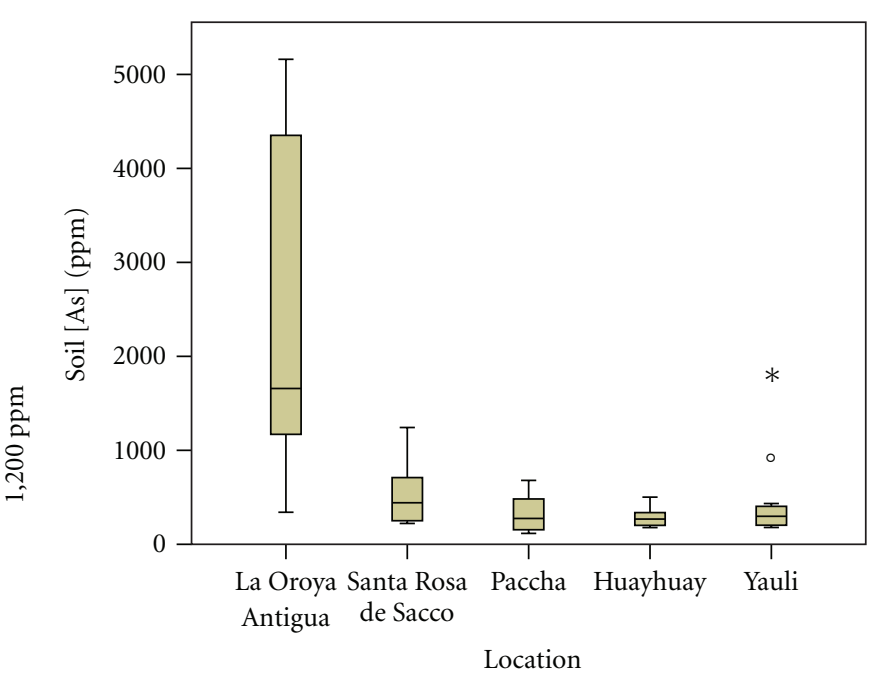

(b)

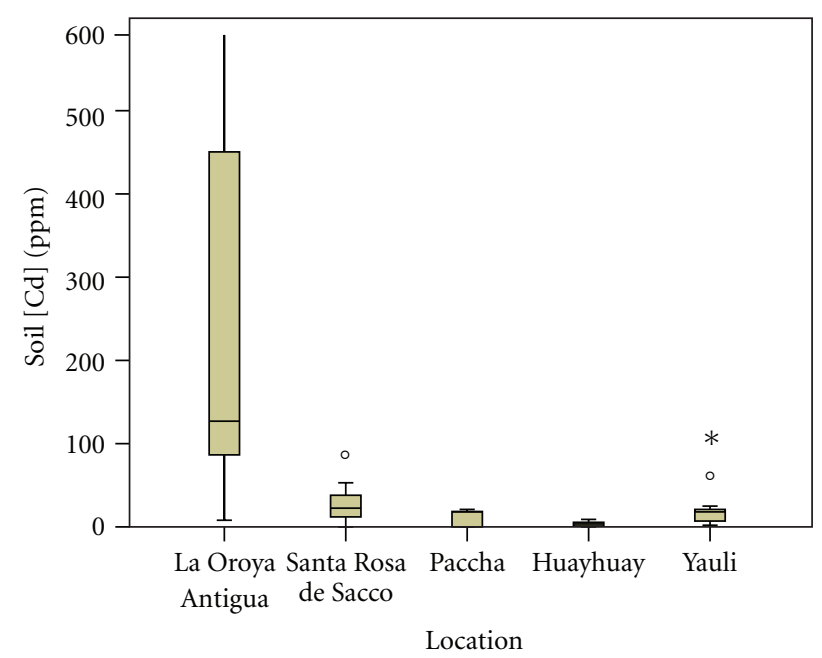

(c)

Figure 2: Box plots of soil $\mathrm{Pb}$, As, and Cd. Results are shown for the five study sites in parts per million. Sites are ordered with increasing distance from the point source. The upper panel includes the USEPA 1,200 ppm reference line for soil Pb (see text for discussion). Horizontal lines denote the median value for each site; box heights indicate the quartile limits (25\% to $75 \%$ ), and error bars reflect the $95 \%$ confidence intervals. Outliers are shown as open circles and asterisks.

than outdoor soil $(186 \mathrm{ppm})$, indicating another potential $\mathrm{Pb}$ source for indoor dust. The same pattern is observed for the Yauli site $(2,228 \mathrm{ppm}$ for indoor dust, 1,623 ppm for soil). This might be explained by leaded paint, which is commonly used and sold in rural Peru (paint chips were also a common component of the indoor dust samples). Elevated soil concentrations might also explain this difference, as small sample populations might not be representative of the larger community.

Because most floor surfaces continuously generate indoor dust in this region, a complementary sampling technique would utilize open Petri dishes for several months to determine deposition rates and metal levels, as discussed by Hogervorst et al. [35] for cadmium and lead. This would not strictly be the same material encountered by children on flooring (some mineral component would also be present), but such samples would better relate anthropogenic aerosols to the indoor heavy metal burden. Isotopic measurements would also help separate multiple indoor dust components.

3.3. Drinking Water Concentrations. Observations of drinking water $\mathrm{Cd}$ and $\mathrm{Pb}$ concentrations follow the general pattern of soil and indoor dust concentrations: elevated values in La Oroya Antigua and lower concentrations in the remaining four sites (see Figure 4). However, $\mathrm{Pb}$ and Cd concentrations are significantly below $1 \mathrm{ppb}$, less than the WHO drinking water guideline values for both metals (10 ppb for $\mathrm{Pb}, 3 \mathrm{ppb}$ for $\mathrm{Cd}$, [36]). This suggests a minimal public health risk (see Section 3.4) for these two metals in the drinking water. Correlating drinking water concentrations to a specific location is difficult, as municipal supplies are sourced far from the communities, stored in protected 


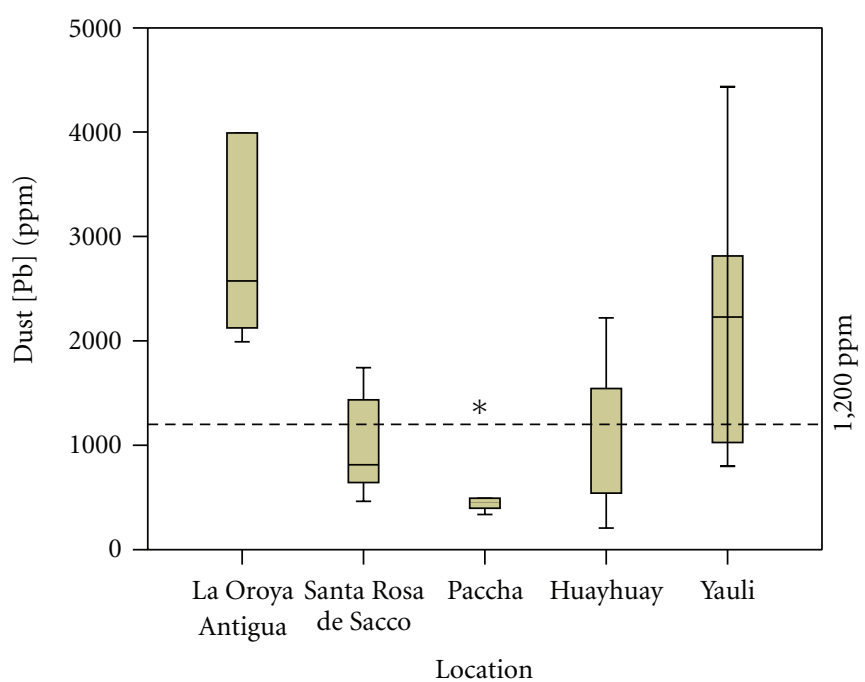

(a)

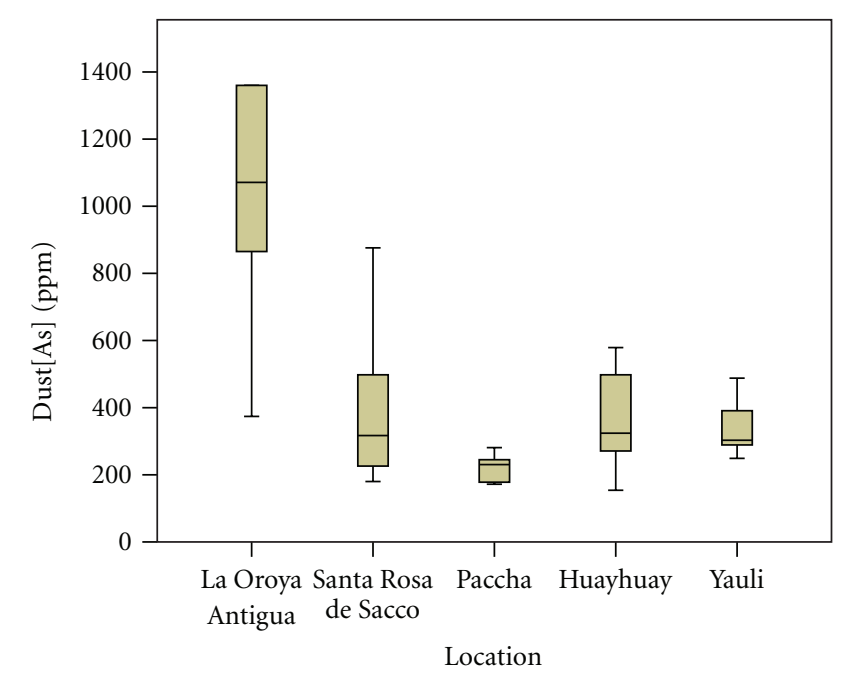

(b)

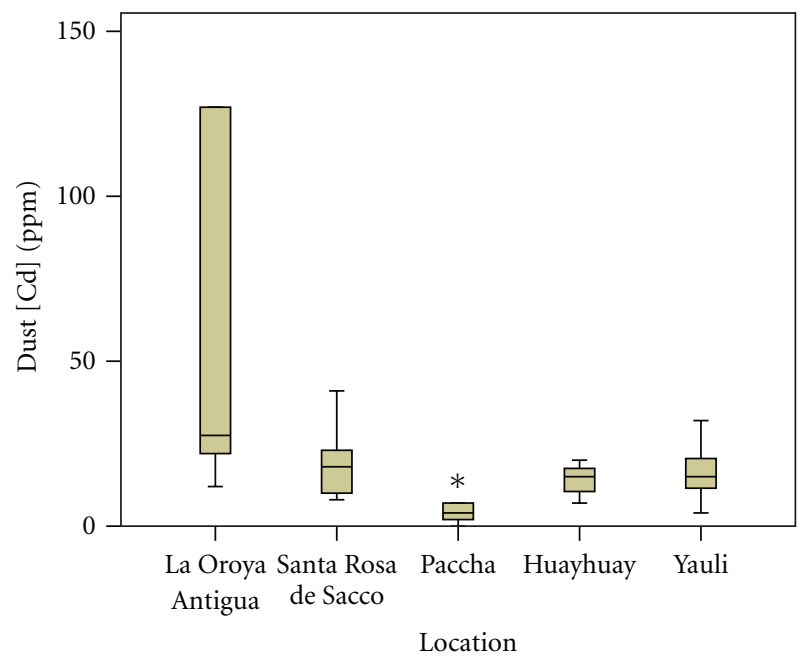

(c)

Figure 3: Box plots of indoor dust $\mathrm{Pb}$, As, and $\mathrm{Cd}$. Results are shown for the five study sites in parts per million. The upper panel includes the USEPA 1,200 ppm reference line (see text for discussion). Horizontal lines denote the median value for each site; box heights indicate the quartile limits (25\% to $75 \%$ ); error bars reflect the $95 \%$ confidence intervals. Outliers are shown as open circles and asterisks.

reservoirs, transported tens of kilometers, and reside locally only until utilized. Thus the local environment might not affect drinking water concentrations for $\mathrm{Pb}$ and $\mathrm{Cd}$.

However, drinking water As concentrations were significantly elevated for La Oroya Antigua (8.5 ppb) and Yauli (11.4 ppb), and individual samples consistently exceeded the $10 \mathrm{ppb}$ WHO drinking water guideline value in Yauli (ibid.). The low variance for As indicates a common drinking water source with high $[\mathrm{As}]$, whereas the variability for $\mathrm{Cd}$ and $\mathrm{Pb}$ supports minor potential inputs from other metal sources, such as lead-containing solder. Of the three elements studied here, As presents the greatest public health concern for drinking water relative to $\mathrm{Pb}$ and $\mathrm{Cd}$. Part of this difference might reflect differential flow through the soil column into groundwater systems - the two divalent cations $\left(\mathrm{Pb}^{2+}, \mathrm{Cd}^{2+}\right)$ may be adsorbed onto clay surfaces or soil organic matter, whereas the various arsenate and arsenite anions might remain soluble through the soil column.

3.4. Risk Assessment. To evaluate the potential health risks in the five communities, we first calculated the heavy metal exposure to children for each metal, using the assumptions given in the Integrated Exposure Uptake Biokinetic Model for Lead in Children dose-response model (IEUBK, Version 1.1, Build 11, February 2010). We utilized the same age cohorts ( 0.5 to 7 years), body weights ( 7.4 to $22.3 \mathrm{~kg}$ ), dust and soil ingestion rates $\left(0.085\right.$ to $\left.0.135 \mathrm{~g} \mathrm{day}^{-1}\right)$, and soil/dust exposure partitioning ( $45 \%$ soil, $55 \%$ dust). Exposure for a particular age cohort and metal is calculated simply as

$$
E(\text { age, metal })=\frac{X \times R_{i} \times f}{m},
$$




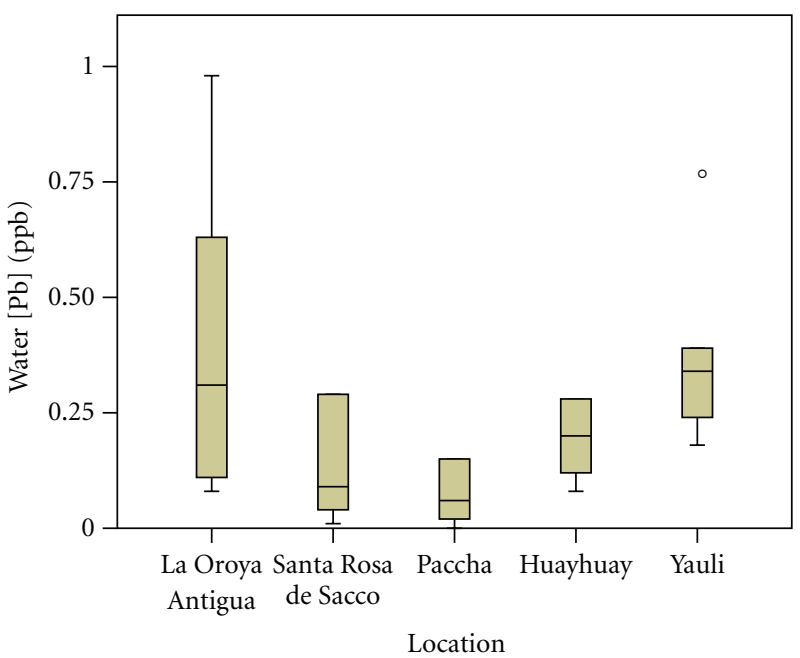

(a)

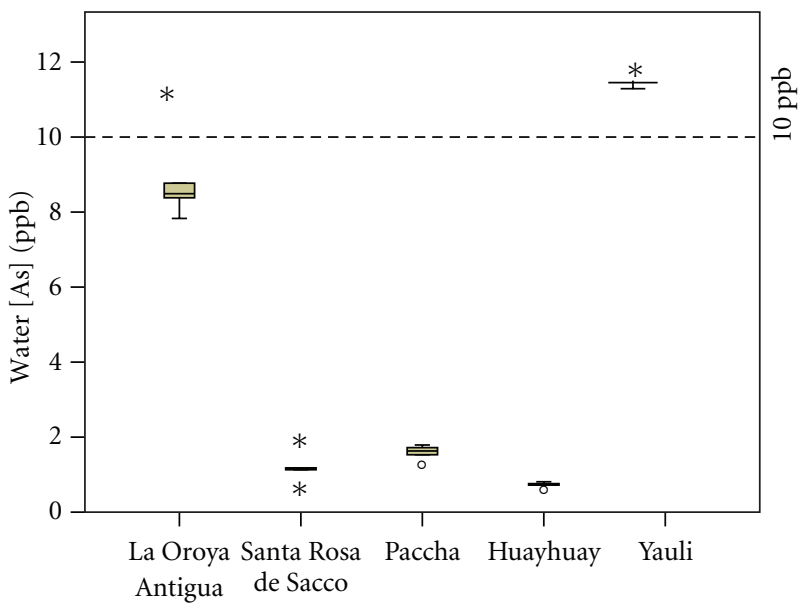

Location

(b)

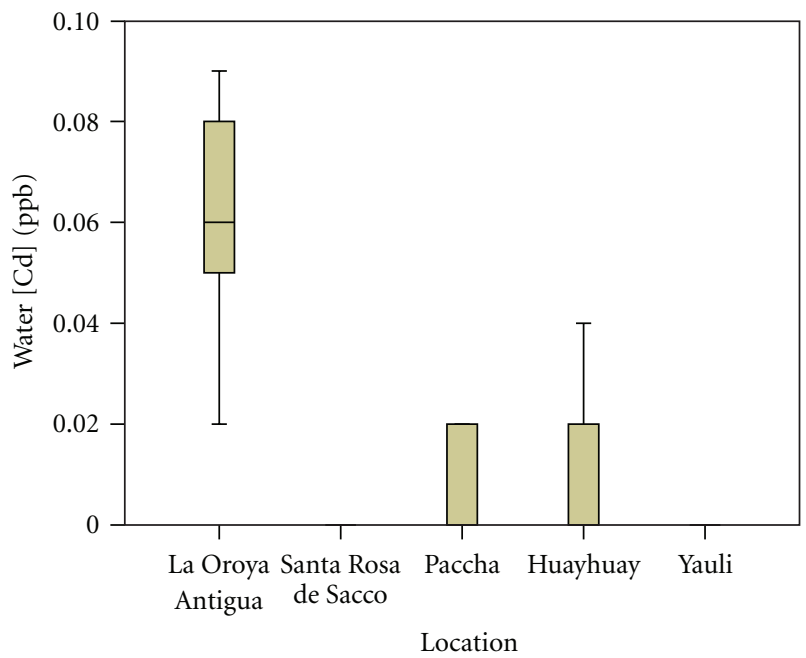

(c)

Figure 4: Box plots of drinking water $\mathrm{Pb}$, As, and $\mathrm{Cd}$. Results are shown for the five study sites in parts per billion. The middle panel includes the $10 \mathrm{ppb}$ WHO reference line (see text for discussion). Horizontal lines denote the median value for each site; box heights indicate the quartile limits (25\% to $75 \%$ ); error bars reflect the $95 \%$ confidence intervals. Outliers are shown as open circles and asterisks.

TABle 2: As, Cd, and Pb exposure calculations by site and sample media. The exposure sum for each site is given in the rightmost column, calculated from the median values for each metal. Please see the text for assumptions and calculations.

\begin{tabular}{|c|c|c|c|c|c|c|c|c|c|c|}
\hline \multirow{2}{*}{ Site } & \multicolumn{3}{|c|}{$\mathrm{Pb}$ exposure $\left(\mu \mathrm{g} \mathrm{kg}^{-1}\right.$ day $\left.^{-1}\right)$} & \multicolumn{3}{|c|}{ Cd exposure $\left(\mu \mathrm{g} \mathrm{kg}^{-1} \mathrm{day}^{-1}\right)$} & \multicolumn{3}{|c|}{ As exposure $\left(\mu \mathrm{g} \mathrm{kg}^{-1} \mathrm{day}^{-1}\right)$} & \multirow{2}{*}{ Sum } \\
\hline & Soil & Indoor dust & Drinking water & Soil & Indoor dust & Drinking water & Soil & Indoor dust & Drinking water & \\
\hline La Oroya Antigua & 12.3 & 12.2 & 0.01 & 0.5 & 0.1 & 0.00 & 6.4 & 5.1 & 0.26 & 36.8 \\
\hline Santa Rosa de Sacco & 4.5 & 3.8 & 0.00 & 0.1 & 0.1 & 0.00 & 1.7 & 1.5 & 0.04 & 11.7 \\
\hline Paccha & 2.4 & 2.2 & 0.00 & 0.1 & 0.0 & 0.00 & 1.1 & 1.1 & 0.05 & 6.8 \\
\hline Huayhuay & 0.7 & 2.8 & 0.01 & 0.0 & 0.1 & 0.00 & 1.0 & 1.5 & 0.02 & 6.2 \\
\hline Yauli & 6.3 & 10.5 & 0.01 & 0.1 & 0.1 & 0.00 & 1.2 & 1.4 & 0.34 & 19.9 \\
\hline
\end{tabular}

where $X$ denotes the mass fraction of a particular metal in an environmental medium (e.g., $3000 \mu \mathrm{g} \mathrm{g}^{-1} \mathrm{~Pb}$ in soil), $R_{i}$ is the daily ingestion rate of the medium $\left(0.1 \mathrm{~g} \mathrm{day}^{-1}\right.$ of soil and dust, age dependent), $f$ reflects the mass fraction of soil versus dust ingestion, and $m$ denotes body mass (also age dependent). For drinking water, $f=1$. The median exposure was calculated for each site, metal, and the seven age cohorts (Table 2).

The IEUBK model has been successfully implemented in regions impacted by smelter emissions to account for blood $\mathrm{Pb}$ observations (see Table 5 of [37]). This model makes several assumptions that are potentially inappropriate for 
TABLE 3: IEUBK model blood $\mathrm{Pb}$ estimates by site and age. For each site, the median $\mathrm{Pb}$ concentration for all three media was included in a model run; all other media were set to zero to evaluate the impact of indoor dust, soil, and drinking water. Blood Pb results are given for each age cohort, the mean, and the $95 \%$ confidence interval (in $\mu \mathrm{g} \mathrm{dL} \mathrm{L}^{-1}$ ).

\begin{tabular}{|c|c|c|c|c|c|}
\hline Age (years) & La Oroya Antigua & Santa Rosa de Sacco & Paccha & Huayhuay & Yauli \\
\hline $0.5-1.0$ & 21.8 & 10.3 & 6.3 & 5.0 & 17.1 \\
\hline $1.0-2.0$ & 25.2 & 12.0 & 7.4 & 5.9 & 19.9 \\
\hline $2.0-3.0$ & 24.0 & 11.3 & 6.9 & 5.5 & 18.8 \\
\hline $3.0-4.0$ & 23.6 & 10.9 & 6.6 & 5.2 & 18.4 \\
\hline $4.0-5.0$ & 20.4 & 9.0 & 5.3 & 4.2 & 15.7 \\
\hline $5.0-6.0$ & 17.7 & 7.4 & 4.3 & 3.4 & 13.3 \\
\hline $6.0-7.0$ & 15.8 & 6.5 & 3.7 & 2.9 & 11.8 \\
\hline Mean $[\mathrm{Pb}]$ & 21.2 & 9.6 & 5.8 & 4.6 & 16.4 \\
\hline 95\% C. I. & 6.9 & 4.1 & 2.8 & 2.2 & 6.0 \\
\hline
\end{tabular}

remote Peruvian villages (e.g., soil ingestion rates). Exposure estimates also do not account for metal uptake or biokinetics, which are significant at high media concentrations given saturation effects. However, this simple exposure calculation serves as a useful remediation guide given order-ofmagnitude differences among sites, media, and metals.

The exposure results suggest there are significant contributions from soil and indoor dust for $\mathrm{As}$ and $\mathrm{Pb}$, with minimal contributions from drinking water. Because much of the indoor dust metal burden derives from outdoor soil [9], this indicates the soil reservoir should be the primary focus of remediation efforts. $\mathrm{Pb}$ and $\mathrm{As}$ exposure are significantly greater than $\mathrm{Cd}$ in this region, suggesting that any remediation must address multiple toxins (not $\mathrm{Pb}$ alone). Finally, three sites show elevated heavy metal exposure relative to the upwind site (Paccha, $6.8 \mu \mathrm{g} \mathrm{kg}^{-1} \mathrm{day}^{-1}$ ) and our control site (Huayhuay, $6.2 \mu \mathrm{g} \mathrm{kg}^{-1} \mathrm{day}^{-1}$ ). These exposure estimates may help establish regional priorities for remediation, focusing on La Oroya Antigua (36.8 $\left.\mu \mathrm{g} \mathrm{kg}^{-1} \mathrm{day}^{-1}\right)$, Yauli $\left(19.9 \mu \mathrm{g} \mathrm{kg}^{-1} \mathrm{day}^{-1}\right)$, and Santa Rosa de Sacco $\left(11.7 \mu \mathrm{g} \mathrm{kg}^{-1} \mathrm{day}^{-1}\right)$. However, we acknowledge other exposure sources should also be measured to better constrain these sites.

To account for metal uptake and biokinetics, we then utilized the IEUBK model to calculate blood $\mathrm{Pb}$ levels for the five sites and age cohorts [26]. These blood $\mathrm{Pb}$ estimates are made using incomplete data (no estimates of dietary, aerosol, maternal, or other $\mathrm{Pb}$ sources were available for this 2010 sampling period); they should be viewed as minimum estimates. To evaluate the impact of soil, indoor dust, and drinking water $\mathrm{Pb}$ on blood $\mathrm{Pb}$ levels at these five sites, the other media values were set to zero in the model. Table 3 shows the IEUBK results.

In agreement with the exposure calculations, drinking water $\mathrm{Pb}$ had negligible effect on blood $\mathrm{Pb}$ concentrations, and indoor dust and soil had concentration-weighted, nonadditive effects. For example, the estimated blood $\mathrm{Pb}$ concentration for La Oroya Antigua was affected equally by indoor dust $(\mathrm{Pb}=2,574 \mathrm{ppm})$ and soil $(\mathrm{Pb}=3,177 \mathrm{ppm})$. Due to the indoor dust and soil $\mathrm{Pb}$ measured in this study, blood $\mathrm{Pb}$ levels equal to or greater than the $10 \mu \mathrm{g} \mathrm{dL}^{-1}$ level of concern were observed for three of the five sites, including
La Oroya Antigua $\left(21 \pm 7 \mu \mathrm{g} \mathrm{dL}^{-1}\right)$, Santa Rosa de Sacco $\left(10 \pm 4 \mu \mathrm{g} \mathrm{dL}^{-1}\right)$, and Yauli $\left(16 \pm 6 \mu \mathrm{g} \mathrm{dL}^{-1}\right)$. Although these estimates contain significant uncertainty, the soil and dust $\mathrm{Pb}$ concentrations likely pose a significant pediatric health issue in the absence of point source emissions. Blood $\mathrm{Pb}$ levels will likely not fall below the WHO $10 \mu \mathrm{g} \mathrm{dL}^{-1}$ level of concern until soil remediation has occurred, notably in La Oroya Antigua. The observations and calculations presented here underscore the importance of appropriate soil remediation in areas impacted by smelter emissions. Alternatively, moving residents from the point source may ultimately limit its health impacts (children requiring chelation therapy are currently housed at the Casaracra site west of La Oroya Antigua). Cessation of the metallurgical complex and soil remediation will result in significantly reduced toxic metal exposures for the children of La Oroya, Peru.

3.5. Further Research. This reconnaissance survey raises several questions regarding the scale of environmental contamination and its associated pediatric health risk. First, to better constrain the contaminated area surrounding the La Oroya smelter complex, additional sites in different directions and larger numbers of samples would supplement the values reported here (often limited due to opportunity sampling); complementary lead isotope measurements would be useful to separate multiple anthropogenic sources such as paint, solder, and aerosols. Depth profiles from known contaminated areas would better elucidate the volume of contaminated soil due to the accumulation and migration of anthropogenic aerosols. Since this study relies on the IEUBK blood lead model to assess pediatric blood lead levels, a direct comparison between blood lead and environmental metal concentrations in La Oroya Antigua would test the model's assumptions for this population. Finally, soil remediation experiments would elucidate the most efficient method for reducing soil $\mathrm{Pb}$, As, and $\mathrm{Cd}$ toxicity.

\section{Conclusions}

This study of the La Oroya district has established several key patterns of $\mathrm{Pb}$, As, and $\mathrm{Cd}$ contamination associated with the metallurgical complex; these patterns are more complicated 
than anticipated from an individual point source. Several key observations from this study include the following.

(i) Elevated heavy metal soil and indoor dust concentrations were observed close to the La Oroya complex with an exponential reduction with distance, following previous studies on smelter emissions. Greatest soil and indoor dust contamination was observed at the La Oroya Antigua site.

(ii) Soils and indoor dust $\mathrm{Pb}$ exceeded the 1,200 ppm USEPA regulatory threshold in three of the five sites. Excluding the Yauli site, the La Oroya point source accounts for the majority of the regional variability for $\mathrm{Pb}$ and $\mathrm{Cd}$. Another contamination source likely accounts for the elevated metal concentrations observed at Yauli.

(iii) Drinking water samples showed $\mathrm{Pb}$ and $\mathrm{Cd}$ concentrations significantly below the WHO guideline values; however, As exceeded the $10 \mathrm{ppb}$ guideline value at two sites (La Oroya Antigua and Yauli). Drinking water remediation should focus on As removal at those sites.

(iv) Exposure calculations and dose-response modeling suggest that soil remediation of $\mathrm{Pb}$ and drinking water remediation of As at La Oroya Antigua, Yauli, and Santa Rosa de Sacco will improve children's health in this region.

In the absence of point source emissions, contaminated soil and indoor dust pose a significant health threat to the children of La Oroya Antigua. Reduced atmospheric pollution from the metallurgical complex will not necessarily return pediatric blood $\mathrm{Pb}$ levels below the $10 \mu \mathrm{g} \mathrm{dL}-1$ WHO level of concern. Thus, the disputed remediation efforts at $\mathrm{La}$ Oroya should focus on soil $\mathrm{Pb}$ and drinking water As, reducing both the environmental and public health burden for the children of central Peru.

\section{Acknowledgments}

The authors gratefully acknowledge the residents of La Oroya, Paccha, Yauli, Huayhuay, and Santa Rosa de Sacco who generously allowed us to sample indoor dust and drinking water in their homes, businesses, and schools for this study. Steve Burt of Colorado College provided expert machining assistance for the syringe press and nylon sieves. They also thank the Kresge Family Foundation, the McKee Family Trust, the Otis and Margaret Barnes Trust, and Colorado College for funding used to provide travel, instrument, and laboratory support for this study. The helpful reviewers' comments greatly improved the quality of this paper.

\section{References}

[1] W. Shotyk, D. Weiss, P. G. Appleby et al., "History of atmospheric lead deposition since 12,370 $14 \mathrm{C}$ yr BP from a peat bog, jura mountains, Switzerland," Science, vol. 281, no. 5383, pp. 1635-1640, 1998.
[2] J. O. Nriagu and J. M. Pacyna, "Quantitative assessment of worldwide contamination of air, water and soils by trace metals," Nature, vol. 333, no. 6169, pp. 134-139, 1988.

[3] J. M. Pacyna, E. G. Pacyna, and W. Aas, "Changes of emissions and atmospheric deposition of mercury, lead, and cadmium," Atmospheric Environment, vol. 43, no. 1, pp. 117-127, 2009.

[4] A. E. Kelly, M. K. Reuer, N. F. Goodkin, and E. A. Boyle, "Lead concentrations and isotopes in corals and water near Bermuda, 1780-2000," Earth and Planetary Science Letters, vol. 283, no. 1-4, pp. 93-100, 2009.

[5] X. Huo, L. Peng, X. Xu et al., "Elevated blood lead levels of children in Guiyu, an electronic waste recycling town in China," Environmental Health Perspectives, vol. 115, no. 7, pp. 1113-1117, 2007.

[6] S. LaFraniere, "Lead poisoning in China: the hidden scourge," The New York Times, 2011.

[7] P. J. Landrigan, S. H. Gehlbach, B. F. Rosenblum et al., "Epidemic lead absorption near an ore smelter-role of particulate lead," The New England Journal of Medicine, vol. 292, no. 3, pp. 123-129, 1975.

[8] T. M. Roberts, T. C. Hutchinson, and J. Paciga, "Lead contamination around secondary smelters: estimation of dispersal and accumulation by humans," Science, vol. 186, no. 4169, pp. 1120-1123, 1974.

[9] S. R. Hilts, "Effect of smelter emission reductions on children's blood lead levels," Science of the Total Environment, vol. 303, no. 1-2, pp. 51-58, 2003.

[10] Y. M. Jiang, H. Shi, J. Y. Li, C. Shen, J. H. Liu, and H. Yang, "Environmental lead exposure among children in Chengdu, China: blood lead levels and major sources," Bulletin of Environmental Contamination and Toxicology, vol. 84, no. 1, pp. 1-4, 2010.

[11] N. C. Munksgaard, M. P. Taylor, and A. Mackay, "Recognising and responding to the obvious: the source of lead pollution at Mount Isa and the likely health impacts," Medical Journal of Australia, vol. 193, no. 3, pp. 131-132, 2010.

[12] B. L. Gulson, D. Howarth, K. J. Mizon, A. J. Law, M. J. Korsch, and J. J. Davis, "Source of lead in humans from Broken Hill mining community," Environmental Geochemistry and Health, vol. 16, no. 1, pp. 19-25, 1994.

[13] M. F. Soto-Jimenez and A. R. Flegal, "Childhood lead poisoning from the smelter in Torreón, México," Environmental Research, vol. 111, no. 4, pp. 590-596, 2011.

[14] G. G. G. Vargas, M. Rubio Andrade, L. M. Del Razo, V. Borja Aburto, E. Vera Aguilar, and M. E. Cebrián, "Lead exposure in children living in a smelter community in Region Lagunera, Mexico," Journal of Toxicology and Environmental Health, Part A, vol. 62, no. 6, pp. 417-429, 2001.

[15] C. L. N. Banza, T. S. Nawrot, V. Haufroid et al., "High human exposure to cobalt and other metals in Katanga, a mining area of the Democratic Republic of Congo," Environmental Research, vol. 109, no. 6, pp. 745-752, 2009.

[16] A. Cederstav and A. Barandiarán, La Oroya Cannot Wait, Sociedad Peruana de Derecho Ambiental, 2002.

[17] A. V. Ramírez, J. C. Paucar, and J. M. Medina, "Blood lead levels in the inhabitants of four Peruvian localities," Revista Panamericana de Salud Publica/Pan American Journal of Public Health, vol. 1, no. 5, pp. 344-348, 1997.

[18] L. W. Chang, Toxicology of Metals, CRC Lewis, Boca Raton, Fla, USA, 1996.

[19] National Research Council, Measuring Lead Exposure in Infants, Children, and other Sensitive Populations, National Academy Press, Washington, DC, USA, 1993. 
[20] B. Fraser, "La Oroya's legacy of lead," Environmental Science and Technology, vol. 43, no. 15, pp. 5555-5557, 2009.

[21] WHO, Air Quality Guidelines for Europe, vol. 91, WHO Regional Publications, Copenhagen, Denmark, 2000.

[22] USEPA, "Lead; identification of dangerous levels of lead; final rule," Federal Register, vol. 66, no. 4, pp. 1206-1240, 2001.

[23] "Doe run resources corporation, form 10-K/A," United States Securities and Exchange Commission, Washington, DC, USA, 2006.

[24] B. P. Lanphear, K. Dietrich, P. Auinger, and C. Cox, "Cognitive deficits associated with blood lead concentrations $<10 \mu \mathrm{g} / \mathrm{dL}$ in US children and adolescents," Public Health Reports, vol. 115 , no. 6, pp. 521-529, 2000.

[25] H. L. Needleman and C. A. Gatsonis, "Low-level lead exposure and the IQ of children. A meta-analysis of modern studies," Journal of the American Medical Association, vol. 263, no. 5, pp. 673-678, 1990.

[26] USEPA, Short Sheet: Overview of the IEUBK Model for Lead in Children, United States Environmental Protection Agency, Washington, DC, USA, 2002.

[27] L. O. Rodriguez and K. R. Young, "Biological diversity of Peru: determining priority areas for conservation," Ambio, vol. 29, no. 6, pp. 329-337, 2000.

[28] R. Ferreyra, "Flora y Vegetación del Perú," in Gran Geografía del Perú, Naturaleza y Hombre, Lima, Peru, 1986.

[29] C. B. Napuri, El Desarrollo Empresarial Desde la Perspectiva Local, Red Académica Iberoamericana Local-Global, Málaga, Spain, 2008.

[30] C. Chuquimantari and Y.-L. Oroya, Mineria y Cuidades Empresa, 1992.

[31] D. M. Payne, "Andean trade preference act," Congressional Record-Extension of Remarks, Washington, DC, USA, pp. E214-E215, 2011.

[32] C. C. Patterson and D. M. Settle, "Review of data on eolian fluxes of industrial and natural lead to the lands and seas in remote regions on a global scale," Marine Chemistry, vol. 22, no. 2-4, pp. 137-162, 1987.

[33] J. M. Pacyna, "Atmospheric emissions of arsenic, cadmium, lead and mercury from high temperature processes in power generation and industry," in Lead, Mercury, Cadmium and Arsenic in the Environment, T. C. Hutchinson and K. M. Meema, Eds., pp. 69-87, Wiley, New York, NY, USA, 1987.

[34] D. Sánchez-Rodas, A. M. Sánchez de la Campa, J. D. de la Rosa et al., "Arsenic speciation of atmospheric particulate matter (PM10) in an industrialised urban site in southwestern Spain," Chemosphere, vol. 66, no. 8, pp. 1485-1493, 2007.

[35] J. Hogervorst, M. Plusquin, J. Vangronsveld et al., "House dust as possible route of environmental exposure to cadmium and lead in the adult general population," Environmental Research, vol. 103, no. 1, pp. 30-37, 2007.

[36] WHO, Guidelines for Drinking-Water Quality, World Health Organization, Geneva, Switzerland, 4th edition, 2011.

[37] L. Carrizales, I. Razo, J. I. Tellez-Hernandez et al., "Exposure to arsenic and lead of children living near a copper-smelter in San Luis Potosi, Mexico: importance of soil contamination for exposure of children," Environmental Research, vol. 101, no. 1, pp. 1-10, 2006. 


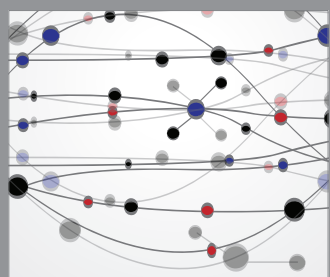

The Scientific World Journal
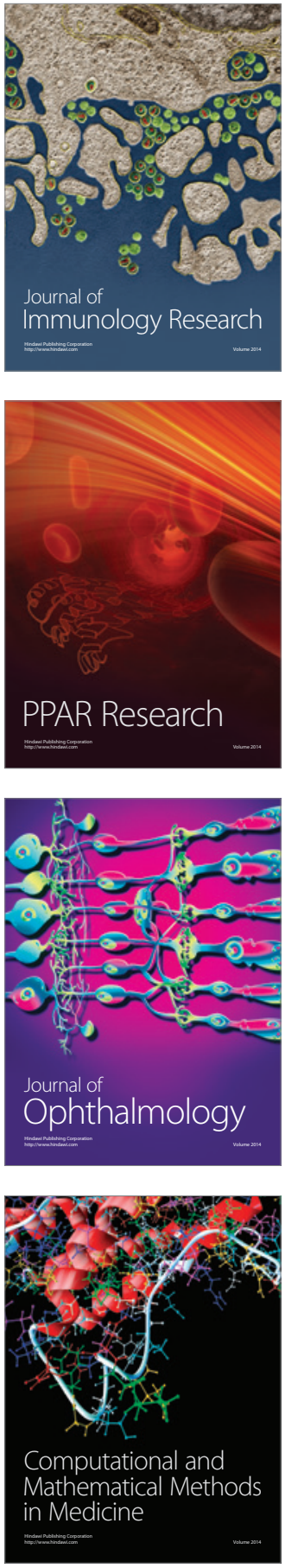

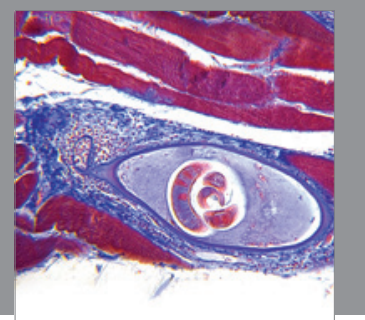

Gastroenterology

Research and Practice
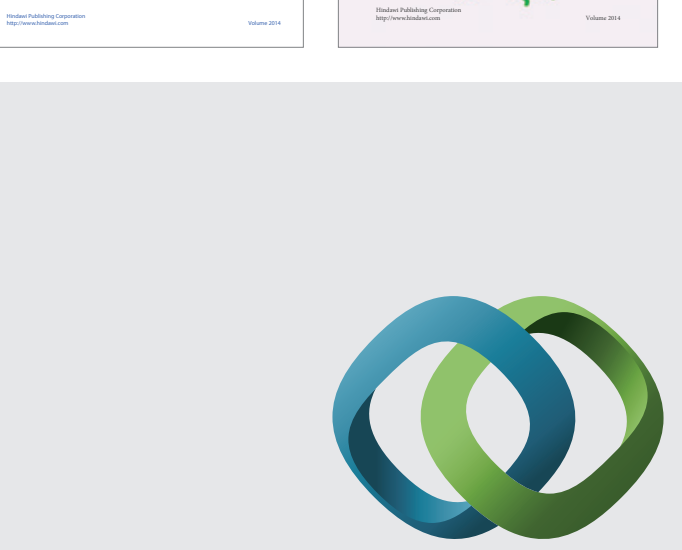

\section{Hindawi}

Submit your manuscripts at

http://www.hindawi.com
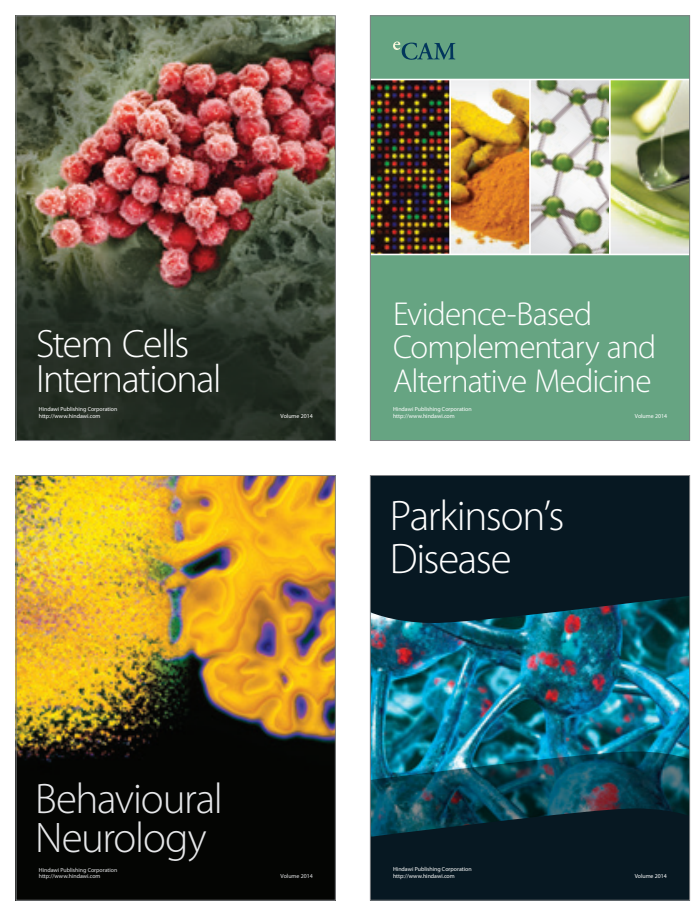

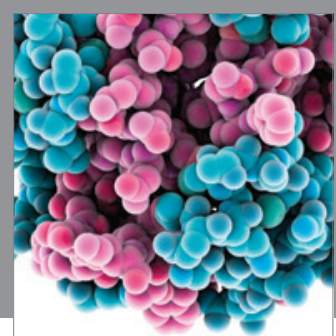

Journal of
Diabetes Research

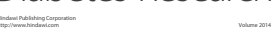

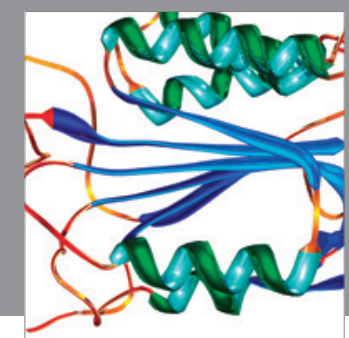

Disease Markers
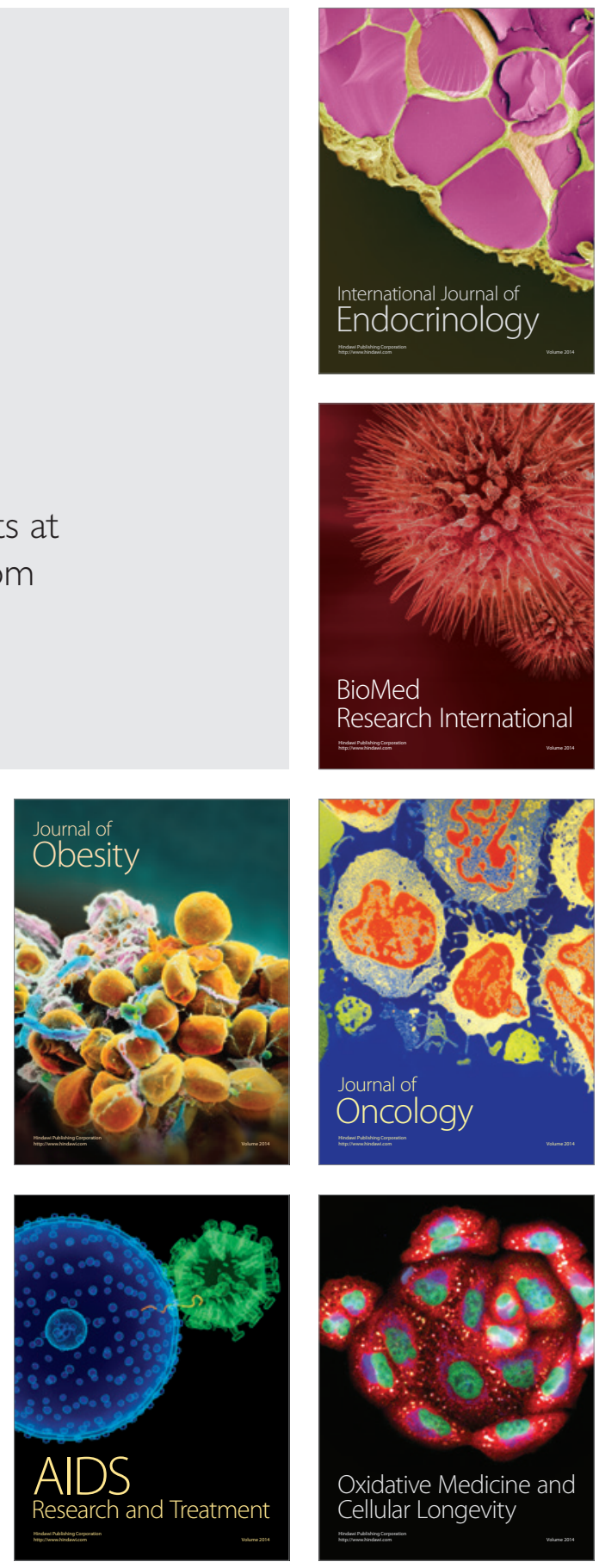